\title{
O CruZEIRO E A REINVENÇÃo de MACHAdO dE ASSIS
}

\section{O CRUZEIRO AND the MACHAdo de AsSis' REINVENTION}

\author{
Jaison Luís Crestani* \\ jaison.crestani@ifpr.edu.br
}

RESUMO: Este artigo apresenta uma análise da colaboração de Machado de Assis nas páginas do jornal O Cruzeiro. O estudo da interação dinâmica do autor com o contexto de produção do periódico permite identificar os traços de sua inscrição singular em projetos editoriais coletivos e os resultados criativos decorrentes da apropriação do conjunto de discursos, códigos e signos que formam a cultura de seu tempo. A dominante estilística do material remetido ao jornal consiste no humor, na paródia, na experimentação formal e na irreverência crítica - aspectos que responderiam pela inscrição da literatura machadiana na tradição da sátira menipeia. Com a análise dessa narrativa, pretende-se demonstrar, portanto, que O Cruzeiro afirma-se como mediador e suporte, por excelência, dos exercícios experimentalistas que resultaram na transformação da prática criativa de Machado de Assis ao final da década de 1870.

PaLAVRAS CHAVE: Machado de Assis, O Cruzeiro, humor, paródia, reinvenção.

ABSTRACT: This paper presents an analysis of Machado de Assis' colaboration in the pages of the newspaper $\mathrm{O}$ Cruzeiro. The study of the dynamic interaction between the author and the periodical's production context permits to identify the traces of his singular inscription in collective editorial projects and the creative results deriving from the appropriation of the group of discourses, codes and signs that form the culture of his time. The dominant stylistic of the material submitted to the journal is the humor, parody, formal experimentation and critical irreverence - these aspects would respond by the inclusion of Machado's literature in the tradition of Menippean satire. Therefore, the analysis of this narrative intends to demonstrate that the newspaper $O$ Cruzeiro is stated as a mediator and support, for excellence, of the experimental exercises that resulted in the transformation of creative practice of Machado de Assis' creative practice at the end of the 1870s.

KEYWORDS: Machado de Assis, O Cruzeiro, humor, parody, reinvention.

\section{Introdução}

Na tradição dos estudos machadianos, a discussão em torno das motivações que desencadearam a transformação dos paradigmas literários de Machado de Assis assume uma dimensão invulgar. Designada como "brusco desvio", "reviravolta", "grande salto", "misteriosa mudança" ou "ruptura radical e repentina", a irrupção dessa inovadora experiência artística costuma ser associada à famosa "crise dos quarenta anos", cujos resultados se manifestariam na composição das Memórias póstumas de Brás Cubas (1881) e no arranjo da coletânea Papéis avulsos (1882).

Embora se reconheça a complexidade intrínseca dessa excepcional metamorfose machadiana, não se trata de uma incógnita absolutamente indecifrável. Tampouco seriam

\footnotetext{
*Doutor em Letras pela Universidade Estadual Paulista Júlio de Mesquita Filho (Unesp). Docente do Instituto Federal do Paraná (IFPR).
} 
plausíveis as diversas explicações de ordem extraliterária evocadas na elucidação de um processo, artisticamente consciente, de reinvenção da forma literária das obras. O impasse interpretativo que essa questão impõe à fortuna crítica do autor resultaria mais propriamente do desvio que os próprios estudos críticos executam em relação à produção intercalada entre a publicação de laiá Garcia e o aparecimento das inusitadas Memórias póstumas de Brás Cubas. O predomínio de uma leitura viciada, que só devota atenção e reconhecimento literário às obras republicadas em livro pelo próprio escritor, somado ao descaso editorial, que negligencia parte considerável dessa produção ou esfacela a sua unidade, atua em desfavor da elucidação das motivações que conduziram o autor a redefinir a sua concepção do fazer literário e a ensaiar uma série de experimentações criativas com o intuito de instituir uma nova dicção artística à sua literatura.

A análise da atividade intelectual de Machado de Assis enquanto homem de imprensa, desenvolvida junto ao jornal 0 Cruzeiro durante o ano de 1878, permite averiguar a sua interação dinâmica com as questões e linguagens de seu tempo, com a audiência, o corpo de colaboradores e a conjuntura editorial do periódico. Da sua colaboração no jornal, interessa salientar, especialmente, a relação de continuidade que se observou entre a série "Fantasias" - inaugurada sob o pseudônimo Rigoletto, que assinou as duas primeiras manifestações, - e as nove produções ficcionais, assinadas pelo pseudônimo machadiano de Eleazar, que executam uma visível apropriação do programa formulado pelo redator anterior. Sob o título de "Filósofos, bobos e folhetinistas", a primeira fantasia publicada por Rigoletto traça a genealogia de um conjunto de autores irreverentes que "sempre se insurgiram contra tudo o que era fictício, falso, assoprado, empavesado, convencional, ridículo e hipócrita", e se empenharam em proclamar a verdade "como ela é, simples, rude, desalinhada talvez", por meio de um humor ácido e corrosivo. Na definição dessa linhagem, são mencionados os precursores dessa tendência humorística e irreverente, com destaque para a explícita menção ao escritor sírio, Luciano de Samósata, que teria consolidado a tradição da sátira menipeia.

Levado a continuar essa seção de "Fantasias", Machado de Assis teve de defrontarse necessariamente com o programa editorial, os modelos literários e os referenciais humorísticos sugeridos pelo iniciador da proposta e amparados pela diretriz editorial do jornal. Da inserção nesse projeto coletivo e da apropriação e continuação de seus motivos, derivariam experimentações fundamentais para o processo de transformação da escrita 
machadiana no final da década de 1870. Dentre os principais influxos do programa da série "Fantasias", destacam-se a incursão e a filiação da produção literária de Machado de Assis aos paradigmas e procedimentos criativos da tradição da sátira menipeia, que teriam contribuído decisivamente para o delineamento da nova dicção assumida pela sua produção literária a partir desse período de transição. Conforme a apreciação de Ivan Teixeira (2005, p. xxix), os reflexos do investimento machadiano na apropriação dessa linhagem literária constituem "a diretriz construtiva de Memórias póstumas de Brás Cubas e Papéis avulsos - verdadeiros programas de uma incrível investigação alegórico-fantástica dos modos de comunicação social do Segundo Reinado brasileiro".

\section{Machado de Assis e a tradição da sátira menipeia}

Na tradição dos estudos machadianos, a relação entre a sátira menipeia e a ficção de Machado de Assis foi demonstrada fundamentalmente por quatro críticos literários: José Guilherme Merquior, Enylton de Sá Rego, Valentim Facioli e Ivan Teixeira. No ensaio "Gênero e estilo nas Memórias póstumas de Brás Cubas" (1972), Merquior inaugura o estudo dessas conexões, salientando a "fusão de humorismo filosófico e fantástico" que converteria o primeiro romance maduro do autor em "um representante moderno do gênero cômicofantástico, também conhecido como literatura menipeia" (MERQUIOR, 2008, p. 140). Amparado nos estudos de Mikhail Bakhtin (2003) a respeito da obra de Rabelais e de Dostoievski, o crítico destaca os cinco atributos principais dessa linhagem literária, que seriam apropriados pela obra madura de Machado de Assis: a) a ausência de qualquer distanciamento enobrecedor na figuração dos personagens e de suas ações; b) a mistura do sério e do cômico, de que resulta uma abordagem humorística das questões mais cruciais: o sentido da realidade, o destino do homem, a orientação da existência etc.; c) a absoluta liberdade do texto em relação aos ditames da verossimilhança; d) a frequência da representação literária de estados psíquicos aberrantes: desdobramentos da personalidade, paixões descontroladas, delírios; e) uso constante de gêneros intercalados.

As apreciações de Merquior são aprofundadas por Enylton de Sá Rego, que, em $O$ calundu e a panaceia (1989), promove uma revisão das limitadas concepções teóricas a respeito da sátira menipeia, provenientes dos trabalhos de Bakhtin. Nesse livro, o crítico amplia o estudo dos precursores dessa linhagem literária, revisitando autores como Sêneca, Luciano, Erasmo e Burton, e a interliga com a nova inflexão ensaiada por Laurence Sterne, que 
acrescenta a essa tradição a opção deliberada por um estilo digressivo, a qual seria denominada como poética da forma livre. Partindo desse exame, o estudioso concentra-se na análise das relações que se evidenciam entre a fiç̧ão machadiana e a tradição luciânica, explorando principalmente a assimilação dos seguintes procedimentos técnicos: "a anatomia e o paradoxo; a paródia e o uso de citações truncadas; o ponto de vista do observador distanciado e o falso pessimismo" (SÁ REGO, 1989, p. 105). Como resultados dessa apropriação machadiana dos paradigmas da sátira menipeia, o crítico destaca as seguintes soluções:

[...] é através do uso sistemático da paródia que os textos associados à tradição luciânica apresentam um hibridismo genérico que lhes serve na superação das formas literárias estabelecidas. Além de seu conteúdo parodístico, tais textos caracterizam-se ainda pela presença de um narrador irônico e distanciado, por uma posição moral essencialmente antiautoritária e por uma extrema liberdade de imaginação frente aos ditames da verossimilhança (SÁ REGO, 1989, p. 165-6).

As proposições de Merquior e de Sá Rego são retomadas por Valentim Facioli que, por sua vez, amplia as conexões entre a sátira menipeia e a forma livre, de Laurence Sterne, por meio da inclusão de autores como Xavier de Maistre e Almeida Garrett, evocados por Brás Cubas na definição do método narrativo praticado em suas Memórias póstumas. Circunscrito à análise deste romance, o estudo de Valentim Facioli (2002) concentra-se especialmente na demonstração das confluências entre o estilo desses autores menipeus e a nova formulação conferida por Machado de Assis ao foco narrativo do romance, que passaria a ser caracterizado pela impostura e pela arbitrariedade narrativa.

Finalmente, esse diálogo machadiano com a tradição menipeia é examinado por Ivan Teixeira em diversos trabalhos, a começar por Apresentação de Machado de Assis (1987), que se mantém ainda circunscrito à aplicação do conceito bakhtiniano de carnavalização e ao aprofundamento das sugestões de Merquior sobre a fusão de humor filosófico e fantástico em Memórias póstumas de Brás Cubas. Em trabalhos posteriores, "Pássaro sem asas ou morte de todos os deuses. Uma leitura de Papéis avulsos" (2005) e O altar e o trono: dinâmica do poder em O alienista (2010), o crítico amplia consideravelmente o esboço conceitual a respeito dos procedimentos da sátira menipeia e da sua apropriação pela obra machadiana. De acordo com suas proposições, essa tendência criativa pressupõe o abandono do equilíbrio previsto pelos gêneros puros da tradição clássica, a combinação extravagante de elementos contrários, o humor disparatado e a paródia ou imitação burlesca das formas consagradas da 
cultura. Fundamentada nessas combinações extravagantes, a apropriação machadiana dos procedimentos da sátira menipeia instituiria o absurdo como equilíbrio, vinculando-se à "tópica camoniana do desconcerto do mundo" e à "lógica do paradoxo, que tanto afirma por negativas quanto nega por afirmações" (TEIXEIRA, 2010, p. 151).

Como se observa, os estudos mencionados atestam a importância da apropriação dos procedimentos criativos da sátira menipeia para o processo de transformação da literatura machadiana. Entretanto, em função do desconhecimento da confluência recíproca que se estabeleceu entre os dois folhetinistas d'O Cruzeiro, a conquista da maturidade artística de Machado de Assis mediante a assimilação da tradição luciânica tem sido concebida como um traço decorrente da sua feição universalista ou como consequência do estalo repentino da genialidade intrínseca do escritor. Em vez de uma opção inusitada no âmbito da literatura brasileira do século XIX, como Enylton de Sá Rego entende a incorporação machadiana dos procedimentos da sátira menipeia, a descoberta desse profícuo filão literário pode ser ressignificada e entendida como resultado da inscrição da ficção machadiana no conjunto de práticas humorísticas coletivas fomentadas no interior do "Folhetim do Cruzeiro".

Desse modo, este trabalho pretende demonstrar como a inserção do escritor nesse projeto coletivo do jornal e a apropriação e continuação de seus motivos contribuíram decisivamente para a experimentação, o aprendizado e o domínio da habilidade humorística, da técnica da paródia e de soluções genéricas e procedimentos formais inovadores no âmbito da literatura brasileira.

\section{A série "Fantasias" e a inserção machadiana na tradição da sátira menipeia}

A primeira manifestação da série "Fantasias", assinada por Rigoletto, em 15 de janeiro de 1878, apresenta uma espécie de programa do conjunto de textos que viria a ser publicado nesse âmbito. Sob o título de "Filósofos, bobos e folhetinistas", o texto se concentra na definição da genealogia do folhetinista contemporâneo, firmando uma linha evolutiva entre os filósofos da antiguidade clássica, os bobos da corte e os escritores que se exercitam nos rodapés dos jornais de seu tempo.

A frase inicial preanuncia a irreverência crítica que prevaleceria na elaboração dos textos da série: "Eu abomino, eu detesto, eu execro tudo o que é convencional". A contundência e o aspecto arrojado dessa insurreição contra as convenções instituídas 
facultam a possibilidade de se pensar que essa afirmação inaugural bem poderia ter sido assinada pelo autor de Brás Cubas. Há que se reiterar: pelo autor de Brás Cubas e não pelo autor de laiá Garcia!

Na sequência, o folhetinista estabelece uma comparação entre a formação da civilização e a constituição do globo terrestre: assim como a crosta exterior do planeta encobre a lava interna, "sempre pronta a fazer irrupção", a sociedade civilizada reveste-se de "polidez e hipocrisia", que dissimulam a "franqueza e brutalidade" da sua compleição interior. Esse descompasso entre as conviç̧ões do indivíduo e as convenções que presidem o seu comportamento social rebaixariam a conduta humana a uma condição ainda mais decepcionante do que um programa ministerial:

Isto quer dizer que o homem, por qualquer lado que o encarem, por fora ou por dentro, deixa sempre muito mais a desejar do que o programa de um ministério, nos tempos em que os ministérios faziam programas. Velharias estas que foram caindo em desuso, porque agora os ministros entram e saem, como os personagens de certos dramas, sem dizerem porque se foram nem nos contarem porque vieram (O Cruzeiro, 15 jan. 1878, p. 1, col. 1).

Para demover esse estado das coisas, Rigoletto convoca os precursores da prática irreverente dos folhetinistas, traçando assim a genealogia desses espíritos ognor frementi:

Mas há espíritos que protestam: sempre os houve. Nos tempos antigos certos filósofos, como Diógenes e Luciano (o dos Diálogos). Na meia idade os bobos: Triboulet, D. Bibas e C. [bobos da corte]. Nos tempos modernos Desgenais e os folhetinistas.

Aqui fica traçada a genealogia desses espíritos ognor frementi ${ }^{1}$ que sempre se insurgiram contra tudo o que era fictício, falso, assoprado, empavesado, convencional, ridículo e hipócrita, enfim, e que gostavam de atirar a verdade pela boca fora como uma peça de Krupp carregada de picrato de potassa $(O$ Cruzeiro, 15 jan. 1878, p. 1, col. 2).

$\mathrm{Na}$ definição dessa linhagem, interessa primordialmente a referência à figura de Luciano de Samósata, autor dos Diálogos dos mortos, que consolidou a tradição da sátira menipeia e exerceu uma influência decisiva na composição das Memórias póstumas de Brás Cubas e na emergência dos procedimentos criativos que a literatura machadiana passaria a exercitar a partir da década de 1880.

\footnotetext{
${ }^{1}$ Que tremem a toda hora.
} 
A assimilação machadiana dos procedimentos criativos da tradição luciânica e da sátira menipeia seria considerada por Enylton de Sá Rego (1989) como uma opção inusitada no âmbito da literatura brasileira do século XIX:

Machado de Assis possuía em sua biblioteca particular os dois volumes das Oeuvres Complètes de Lucien de Samosate, numa tradução francesa de 1874 com introdução e notas por Eugène Talbot [...]. A simples presença da obra de Luciano na biblioteca de Machado mostra, portanto, um interesse inesperado por parte de um escritor brasileiro no século dezenove, posto que Luciano, naquela época, era um escritor praticamente desconhecido (SÁ REGO, 1989, p. 86).

No entanto, a alusão de Rigoletto ao autor sírio dá abertura para uma redefinição das conjunturas culturais que determinaram esse profícuo cruzamento da atividade criativa machadiana com a tradição, praticamente desconhecida no Brasil, de Luciano de Samósata. Desse modo, essa confluência intertextual, que contribuiu decisivamente para o "salto qualitativo" das obras da maturidade artística de Machado de Assis, pode ser ressignificada e entendida, não como decorrência da feição universalista do escritor, mas como resultado dessa interação dinâmica com o programa da série "Fantasias", definido por Rigoletto com base em referências filosóficas e literárias que se tornariam decisivas para a transformação da literatura machadiana.

Conforme a hipótese em averiguação, ao ser encarregado de dar continuidade ao programa da seção "Fantasias", Machado de Assis teve de se defrontar necessariamente com o programa, com os modelos literários e com os referenciais humorísticos sugeridos pelo iniciador da proposta e amparados pela diretriz editorial do jornal. Da inserção nesse projeto coletivo e da apropriação e continuação de seus motivos, derivariam, portanto, experimentações fundamentais para o processo de transformação de sua escrita, ocorrido no final da década de 1870.

No marco inicial da genealogia desses espíritos irreverentes, Rigoletto inclui, em parceria com Luciano de Samósata, a figura de Diógenes de Sínope, que viveu na Grécia antiga por volta de 440 a.C. Na busca pelo ideal cínico da autossuficiência de uma vida natural e livre das luxúrias da civilização, o filósofo grego decidiu viver na miséria, habitando um grande barril como lar e carregando, à luz do dia, uma lanterna acesa à procura de um homem honesto. Por acreditar que a virtude era melhor revelada na ação e não na teoria, Diógenes ficou famoso pela ironia incisiva com que combateu as instituições e valores da sociedade 
corrupta e arrogante de seu tempo. Um dos exemplos mais famosos dessa prática, citado no conto machadiano "O espelho", seria a irônica refutação da tese de Zenão (para quem o movimento não existia) por meio de uma simples demonstração: levantou-se em silêncio e começou a andar de um lado para o outro.

Em uma posição intermediária dessa linhagem histórica, Rigoletto menciona a contribuição de dois célebres bobos da corte francesa: D. Bibas, que pertencia à corte do conde D. Henrique, do final do século XI, e Triboulet, o mais famoso deles, que fez parte das cortes de Luís XII e Francisco I, figurando, inclusive, em composições dramáticas de Victor Hugo e no Rigoletto, de Giuseppe Verdi. Essa ópera cômica italiana em três atos, com libreto de Francesco Maria Piave e inspirada na peça Le roi s'amuse, de Victor Hugo, estreou no teatro La Fenice, em Veneza, no ano de 1851. Dela provém o pseudônimo utilizado por esse assíduo colaborador de $O$ Cruzeiro, que ajusta a escolha da sua identidade fictícia à performance humorística a ser exercitada ao longo das manifestações da série "Fantasias".

Finalmente, nos tempos modernos, a irreverência crítica ficaria ao encargo de Desgenais e dos folhetinistas. De acordo com Silvia Cristina Martins de Souza (2006), o teatro realista introduziu uma nova personagem - o raisonneur -, que passaria a exercer a função de porta-voz das ideias e das lições moralizantes do autor às plateias. ${ }^{2} \mathrm{O}$ primeiro raisonneur apareceu na peça As mulheres de mármore, de Théodore Barrière e Lambert Thiboust, representada no Teatro Ginásio Dramático do Rio de Janeiro em 1855. Nessa primeira aparição, esse porta-voz autoral recebeu o nome de Desgenais, que constituía uma derivação do nome do lendário filósofo grego Diógenes. Essa denominação prevaleceria em grande parte dos textos de crítica teatral no Brasil, como se observa em ensaios do próprio Machado de Assis. Em sua apreciação de um drama de Quintino Bocaiúva, intitulado "Os mineiros da desgraça", o autor caracterizaria essa personagem dramática nos seguintes termos:

A figura obrigada dos dramas modernos, conhecida geralmente pelo nome de Desgenais, também entra no drama. Essa é sempre a parte do autor; é pela boca sentenciosa do moralista que o dramaturgo moderno lança as censuras aos vícios da sociedade. O Desgenais da peça é rude e grave, franco e digno. Diz aquilo que pensa, porque tem o tato dos homens com quem lida,

\footnotetext{
2 "Intencionalmente concebida para aliciar o espectador, esta personagem, na visão dos dramaturgos realistas, exercia um grande poder persuasivo sobre as plateias, fazendo com que elas introjetassem as ideias que saíam de sua boca, ao mesmo tempo em que colocava nas mãos dos teatrólogos uma arma poderosa para influenciar os espectadores, resultando disto a importância da qual esta personagem passou a ser revestida" (SOUZA, 2006, p. 240).
} 
e sabe que a dignidade não é o traço distintivo deles. O moralista é sempre audaz, por isso mesmo que representa a minoria da sociedade. Em minha opinião, o moralista nunca pode deixar de ser uma figura de convenção. Entre nós, pelo menos. É por isso que eu acho que não se deve exigir do autor as razões por que o fez orador ou não, e por que em tal ocasião não foi menos grave, e em tal outra, menos jovial. Ele é sentencioso, é quanto basta; ele censura, ele toca na chaga com a tranquilidade do médico, com isso nos devemos contentar (ASSIS, 1951, v. 30, p. 182).

Em síntese, a linhagem traçada por Rigoletto promove uma combinação entre irreverência crítica, inclinação humorística e correção moral. Comprometido com esses pressupostos, o escopo central de seu programa propõe combater a hipocrisia das convenções sociais e proclamar a verdade tal "como ela é, simples, rude, desalinhada talvez". Desse modo, para demover o véu da dissimulação social, o folhetinista recorre à incontinência verbal desses espíritos irreverentes, que atiravam a verdade pela boca afora com um efeito explosivo comparável a "uma peça de Krupp carregada de picrato de potassa". ${ }^{3}$

Como traço comum dessa linhagem, Rigoletto salienta a condição independente e a liberdade de expressão que essas figuras irreverentes forjaram no decurso de sua prática discursiva. No que se refere à performance do folhetinista, sua franqueza e autonomia seriam asseguradas principalmente pela especificidade do espaço em que são inscritas as suas manifestações no corpo do jornal. Dessa forma, para o folhetinista do Cruzeiro, a linha que divisa a parte superior e o rodapé da página do periódico determinaria igualmente os limites entre a verdade e a conveniência social: “Lá em cima está a convenção; cá em baixo expandese a sinceridade". Por meio desse paralelo, Rigoletto assevera que "o grau de civilização de um povo" pode ser medido por uma "escala graduada à margem de um jornal". Assim, "à proporção que o filete do folhetim for invadindo as regiões superiores do palavreado convencional, o progresso da humanidade irá triunfando. Quando o jornal for absorvido pelo

\footnotetext{
${ }^{3}$ A analogia faz referência às invenções bélicas de Alfred Krupp (1787-1860), continuadas posteriormente por seu filho, Friedrich Alfred Krupp. A empresa da família alemã foi responsável pela fabricação de potentes canhões de aço, munições e outros equipamentos de guerra. A fórmula química do picrato de potássio era utilizada como propriedade explosiva desses armamentos. O exército brasileiro importou canhões Krupp fabricados na Alemanha, que foram usados para atacar o arraial de Antônio Conselheiro, durante a Guerra de Canudos, e ficaram conhecidos como "a matadeira". Em uma publicação da Revista Illustrada, faz-se referência ao poder de destruição dessas modernas invenções bélicas: "A arte de destruir a humanidade nem sempre dispôs de instrumentos tão aperfeiçoados, como hoje temos. O canhão Krupp e os mil bromuretos e cloruretos de mercúrio e de potássio são descobertas modernas que a civilização e a medicina reclamam como glórias suas. [...] Todos os meios de matar à la minute pertencem ao nosso século, ao século das grandes invenções (Revista Illustrada, 4 maio 1878, p. 3).
} 
folhetim, o reinado da verdade estará estabelecido na terra" (O Cruzeiro, 15 jan. 1878, p. 1, col. 3).

Na sequência, o folhetinista aplica-se a colocar em prática os preceitos de seu programa e passa a denunciar a hipocrisia que domina os diversos segmentos da sociedade de seu tempo: no parlamento, "pronunciam-se imensos discursos cheios de flores de retórica"; nos bailes, a amabilidade com que um marido oferece o braço à esposa e a conduz ao buffet dissimula os verdadeiros sentimentos que dominam a vida privada do casal, em que seriam "capazes de se engolirem"; na casa de um ministro, o "Palinuro4 do Estado" deixa de receber as pessoas que o procuram para se deliciar "nas combinações do basto e da espadilha"; no campo intelectual, um historiador publica "um volume de histórias (desculpem, lá foi um s demais)", seu talento é aclamado na imprensa e, por fim, verifica-se que a obra fora encomendada a "um amanuense habilidoso de secretaria". Além dessas dissimulações, Rigoletto descortina o conjunto de vícios e delitos praticados nesse círculo social, tais como a vaidade feminina, que leva as mulheres pobres a arrastar "sedas forradas" nos bailes e "em casa trazem rotos os filhos"; a ambição do banqueiro, "que prepara aos olhos de Deus e de todo o mundo um rombo tremendo de infindos milhões de contos a seus credores"; e as práticas fraudulentas do padre "que prega sermões alheios" e do deputado "que encomenda aos literatos os seus relatórios".

Nesses termos, Rigoletto manifesta a sua devoção aos "encantos nus" da verdade e a sua abominação pela "fraudulagem mentirosa" da "linguagem convencional e balofa" que domina a vida pública:

O palavreado domina o mundo, imunda-o...

Words! Words! Words!

Palavras! Palavras! Palavras!

Mas os que gostarem de saber alguma coisa do mundo como ele é, hão de vir bater à porta dos que riem de tudo, dos que conhecem os barbantes dos títeres, dos que nada querem, nada ambicionam, dos que andam na rua com o chapéu na nuca, o que equivale, dada a diferença das épocas, ao célebre tonel de Diógenes (O Cruzeiro, 15 jan. 1878, p. 1, col. 6).

O fragmento citado enaltece a independência de espírito e o estilo despretensioso dos folhetinistas que, à maneira de Diógenes, encontram, nesse "cantinho do mundo que se chama o rodapé de um jornal", o tonel para aninhar as diminutas porções de verdade que

\footnotetext{
${ }^{4}$ Personagem da Eneida, de Virgílio, Palinuro é o piloto do navio de Eneias, que, no canto V, é dominado pelo sono, cai ao mar e desaparece.
} 
ainda subsistem em meio à hipocrisia generalizada. Além disso, ao se reportar às palavras de Hamlet, da tragédia homônima de Shakespeare, Rigoletto acrescenta mais um importante referencial à linhagem dos espíritos irreverentes que fundamenta o programa das suas "Fantasias". Na cena II do segundo ato da peça shakespeariana, Hamlet simula estrategicamente a sua própria loucura para tentar vingar a morte de seu pai, ao mesmo tempo em que denuncia, por meio da desconexão de seu discurso, a vacuidade das palavras, utilizadas para encenar valores e parâmetros humanos que, na realidade, não são efetivamente praticados.

Afora o legado de Shakespeare, Rigoletto convoca, no desfecho de sua fantasia inaugural, uma série de autores irreverentes que participariam, igualmente, da composição do referencial teórico-literário que fundamenta o programa da seção introduzida nas páginas de $O$ Cruzeiro e continuada posteriormente por Eleazar:

Diógenes, Luciano, P. L. Courier, ${ }^{5}$ H. Heine, ${ }^{6}$ Voltaire, ${ }^{7}$ e tu, divino autor de $D$. João e de Child Harold, ${ }^{8}$ vós que conhecestes a natureza humana e arrancastes a máscara aos Tartufos, ${ }^{9}$ que nunca tomastes a sério a inépcia pretenciosa, nem o falso patriotismo, nem as hierarquias factícias, nem os esplendores da riqueza, nem a ciência oficial, nem as falsas vocações, deitai um puro raio dessa imensa auréola que cerca vossas frontes imortais sobre o pobre diabo que em vossos livros bebeu o ódio da hipocrisia, para que possa repartir com seus semelhantes uma molécula sequer dessa eterna verdade que vós derramastes em torrentes sobre a humanidade

\footnotetext{
${ }^{5}$ Paul-Louis Courier (1772-1825) participou da campanha de Napoleão na Itália. Sua fama resultou especialmente de escritos políticos de caráter liberal, intitulados Panfletos (1824).

${ }^{6}$ Poeta romântico alemão, Christian Johann Heinrich Heine (1797-1856) manteve, em suas obras, um expressivo engajamento social e político. Influenciado pelos ideais da Revolução Francesa, protestou contra o conservadorismo hipócrita da arte e da política alemãs. Conhecida por seu sarcasmo e ironia, sua obra, considerada subversiva, foi censurada pelas autoridades alemãs e o poeta foi proibido de viver em sua terra natal, permanecendo em exílio na França.

${ }^{7}$ François Marie Arouet (1694-1778), mais conhecido como Voltaire, pseudônimo com que assinava suas obras, foi um escritor e filósofo iluminista francês. Defensor da reforma social e do liberalismo político e religioso, foi um dos precursores dos ideiais da Revolução Francesa. Suas ideias revolucionárias acabaram por fazer com que fosse exilado de seu país de origem.

${ }^{8}$ D Juan e Peregrinações de Child Harold são obras do escritor inglês George Gordon Byron (1788-1824), mais conhecido como Lord Byron e considerado como o poeta mais cultuado de todo o Romantismo. Tanto a vida quanto a obra do poeta britânico são marcadas pelo domínio da extravagância boêmia. Renegando as convenções puritanas de sua pátria, Byron dedicou grande parte de sua vida a andanças aventureiras e dissolutas pela Europa, o que Ihe rendeu a reputação de revolucionário perigoso. Com uma ampla inflexão autobiográfica, sua obra poética reflete a exuberância de sua vida mundana e as desventuras sentimentais que marcaram a trajetória tempestuosa do poeta.

${ }^{9}$ Tartufo é a personagem de uma das comédias mais famosas da língua francesa de todos os tempos, composta por Molière e intitulada Le Tartuffe (1664). Utilizando-se de uma linguagem cômica e mordaz, o dramaturgo francês promove uma implacável desconstrução da hipocrisia que dominava a estrutura social, religiosa e política de sua época. Tartufo se tornaria, assim, a personagem-símbolo da trapaça e da falsidade religiosa.
} 
deslumbrada, embora para isso lhes já preciso designar-se com o modesto nome do pobre

RIGOLETTO.

Como se observa, Rigoletto invoca um amplo repertório literário, formado por obras elaboradas sob o signo da ironia, do humor e da subversão irreverente dos valores socialmente instituídos. Engajados com ideais revolucionários, os autores elegidos como modelos partilham do propósito de promover a desconstrução da hipocrisia e do convencionalismo que presidem as relações de sociabilidade.

\section{A série "Fantasias" e a apologia do riso e da loucura}

A segunda manifestação da série "Fantasias", intitulada "Política e relógios de pau" e publicada no dia 22 de janeiro de 1878, amplia a definição do programa da seção e do gênero de textos que se pretende abrigar sob essa rubrica. Por meio de um contraponto entre os incômodos do juízo e os benefícios da fantasia, Rigoletto elucida o conceito que fundamenta a designação da série e orienta o manejo da escrita no decurso de suas manifestações fantasiosas:

Eu nasci com juízo e não o perdi depois: deitei-o fora, porque me incomodava. [...]

Quando eu tinha juízo, curvava-me a todas as fatuidades, guardava silêncio a respeito de todos os desaforos, sujeitava-me a todas as imposições, trabalhava como um mouro, poupava como um avarento, e passava a vida triste e macambuzio.

Um belo dia atirei o juízo pela janela fora, e o mundo que eu até ali via à luz mortiça de borras de azeite apareceu-me de repente, como encanto, iluminado por fogos de Bengala.

Amei as mulheres, fiz espumar o champagne, joguei um jogo louco, atirei dinheiro às mancheias ao sio do prazer, crivei-me de dívidas, e briguei; mas tive sensações, gozei, vivi!

O juízo pode dar tudo menos a felicidade (O Cruzeiro, 22 jan. 1878, p.2).

No excerto citado, percebe-se não só uma ampliação do diálogo intertextual com a obra extravagante e a vida boêmia de Lord Byron, já estabelecido na primeira fantasia de Rigoletto, mas também uma extensão da relação dialógica com a obra Elogio da loucura (1511), de Erasmo de Rotterdam. A título de exemplo, basta comparar o fragmento transcrito com algumas breves passagens da obra do humanista holandês, em que a loucura, detentora da voz narrativa, exalta os prazeres da vida mundana e condena as agruras do trabalho: "Sou filha do prazer e do amor livre" (ERASMO, 2005, p. 24); "quanto mais o homem se afasta de 
mim, menos vem a gozar da vida" (p. 30); "um trabalho mental assíduo, denso e penoso, faz com que lentamente, se esgotem os espíritos e a seiva da vida" (p. 33).

Essa apropriação do leitmotiv do livro do escritor holandês adquire uma importância fundamental para a definição das conjunturas culturais que conduziram Machado de Assis à decisão de inscrever a sua produção madura no circuito da tradição da sátira menipeia. Nesse sentido, cumpre salientar que Erasmo prestou uma contribuição decisiva para a consolidação e propagação do legado luciânico na Europa. Conforme a indicação de Enylton de Sá Rego (1989, p. 70), o escritor holandês, em parceria com seu amigo Thomas More, ${ }^{10}$ traduziu do grego para o latim uma coleção de 32 diálogos de Luciano, que foram publicados em Paris no ano de 1506. Além disso, na carta-prefácio dirigida a Thomas More, que introduz a obra Elogio da loucura, o autor explicita a opção deliberada de "ressuscitar a antiga comédia", assumindo a dicção de um "novo Demócrito"11 e de um "novo Luciano" (ERASMO, 2005, p.12).

Além dessa filiação à tradição menipeia, convém salientar também a conotação subversiva assumida pela obra de Erasmo, que promove uma apreciação decididamente satírica das práticas corruptas da Igreja Católica. Embora afirme que o propósito do livro "não é investigar e satirizar a existência dos prelados e dos sacerdotes", a obra conduz uma severa denúncia da conduta viciosa dos religiosos na sua "faina de recolher dinheiro" (p. 158), na constante deturpação do sentido bíblico em benefício próprio e na particular tirania que exercem sobre o povo "com cerimônias ridículas, com berros e ameaças" (p. 144). Nessa depreciação mordaz, associa a eloquência dos pregadores à dos charlatães, acusa os religiosos de apaziguar os desgostos matrimoniais de suas devotas e conclui que "a religião cristã se adapta perfeitamente à loucura e não tem qualquer espécie de relação com a sabedoria" ( $p$. 180).

\footnotetext{
${ }^{10} \mathrm{O}$ escritor e estadista britânico Thomas More (1478-1535) foi condenado à morte por se negar a reconhecer a autoridade do rei Henrique VIII, que se autodeclarou chefe supremo da Igreja da Inglaterra. Posteriormente, More seria canonizado pela Igreja Católica por sua fidelidade. Sua obra mais famosa é Utopia (1516), na qual criou um reino imaginário, que costuma ser entendido ou como uma proposta idealizada de Estado e ou como sátira da Europa do século XVI.

11 O filósofo grego Demócrito de Abdera (460-370 a.C.), contemporâneo de Sócrates, ficou conhecido por sua teoria atômica, que deu origem a uma teoria ética, baseada em um sistema puramente determinístico. Em sua concepção, a liberdade de escolha era uma ilusão, já que não podemos alcançar todas as causas que levam a uma decisão. Demócrito também ficou conhecido como o filósofo que ria de tudo e que acreditava que o riso era o melhor remédio para aliviar os males da humanidade.
} 
Na sequência, o encômio de Rigoletto aos benefícios da fantasia estabelece uma conjunção entre essa opção deliberada pelo domínio do fantástico e os conceitos de loucura, riso e subversão, tornando ainda mais evidente o intertexto com a obra de Erasmo:

Eu só fui feliz quando segui a fantasia. Nunca achei coisa boa neste mundo que não fosse rudemente anatemizada pelo bom e são juízo. Por isso agito sempre ruidosamente por cima da minha cabeça o cetro da ridente loucura; santa loucura! que me faz ver as coisas todas às avessas mas de uma maneira tão divertida! (O Cruzeiro, 22 jan. 1878, p. 2, col. 2).

O escopo central dessa segunda fantasia alinha-se igualmente ao propósito de desmascarar as hipocrisias sociais por meio da irreverência crítica e do humor corrosivo. Conforme estampado no título, o alvo principal da sátira desconstrutiva incide sobre os desmandos da política. Assim, o folhetinista fantasioso exercita a sua predisposição a "ver as coisas todas às avessas" e se propõe a revelar a opinião da fantasia sobre os homens públicos, evitando assim a reiteração do senso comum instituído pelo juízo:

Os políticos parecem-me umas poucas moscas pousadas sobre a despensa de um grande paquete transatlântico da força de 5.000 cavalos.

Com uma pequena diferença. As moscas dos paquetes vão comendo alguns restos de açúcar que o despenseiro deixou cair por fora, e as moscas políticas estão profundamente convencidas de que são elas quem faz andar o paquete, quem o governa, quem o dirige, quem o leva a porto de salvamento (O Cruzeiro, 22 jan. 1878, p. 2, col. 2).

Cerceando a altiva presunção dos homens públicos, Rigoletto afirma que quem realmente governa o Brasil e todo o universo é o sol, do qual dependem as boas colheitas e, por extensão, "todos os confortos da vida". O olhar sardônico do folhetinista descortina a habilidade oportunista com que os políticos tiram partido dos tempos de abundância para se congratular com o povo e simular que, "graças às suas sábias providências, o país caminha a passos longos na estrada da civilização". Porém, quando "a natureza se mostra madrasta" e escasseia a produção, a providência política "derrama sobre as populações angustiadas uma chuva de papel". Rigoletto denuncia, portanto, a inépcia das ações públicas, que restringe todos os projetos da nação ao domínio do "papelório" e da encenação retórica: "words, words, words" - como diria o príncipe da Dinamarca, na tragédia de Shakespeare.

Tanto o motivo da inconstância da natureza como a sátira à retórica vazia e espetaculosa mantém uma inequívoca conformidade com as proposições do Elogio da loucura. Ao se reportar ao fatídico descontentamento do ser humano, as palavras do escritor holandês preanunciam as apreciações de Rigoletto, afirmando que a natureza "muitas vezes 
atua mais como madrasta do que como mãe" (p. 46). Não se pode deixar de incluir, nesse conúbio, o encontro de Brás Cubas com Pandora, a qual também seria concebida como "mãe e inimiga". O esboço programático da série "Fantasias", proposto por Rigoletto, e as manifestações subsequentes de Eleazar confluiriam, de igual modo, com o intuito da obra de Erasmo de representar a "comédia" da vida humana, em que "cada um surge diferente de si próprio", pois sempre representa o seu papel "com máscara" (p. 58).

Na carta-prefácio que introduz o Elogio da loucura, Erasmo renega a originalidade e a autoria individualizada de sua obra para filiá-la a uma linhagem de "inúmeros grandes homens" que estariam igualmente familiarizados com essa prática de "tratar assuntos graves de modo pueril":

Efetivamente, há muitos séculos, Homero escreveu a sua Batraquiomaquia, Virgílio cantou o mosquito e a amoreira, e Ovídio a nogueira; Polícrates veio a estabelecer o elogio de Busíris, depois impugnado e corrigido por Isócrates; Glauco elogiou a injustiça, o filósofo Favorino enalteceu Tersites e a febre quartã; Sinésio, a calvície e Luciano, a mosca parasita; por fim, Sêneca pôs em ridículo a apoteose de Cláudio, Plutarco compôs o diálogo do grilo com Ulisses, Luciano e Apuleio escreveram do burro; e um certo Grunnio Corocotta redigiu o testamento do porco, que São Jerônimo cita (ERASMO, 2005, p. 13).

Filiando-se a essa tradição de autores cômicos e extravagantes, Erasmo afirma que, para se divertir, já jogou xadrez e já montou "em cavalinho de pau, tal qual um menino". O escritor estabelece, assim, uma correspondência progressiva, "adequada a cada idade", entre as fantasias da criança e as pilhérias da vida adulta, que se revestiriam de sérios intuitos e poderiam proporcionar maior proveito do que os "profundos e luminosos assuntos" da retórica e da filosofia (ERASMO, 2005, p. 13). Posteriormente, no decurso de sua obra, o autor demonstra o quanto a sensibilidade humana se mostra atraída pelo universo da ficção em comparação com o pouco interesse que manifesta pela seriedade das demonstrações filosóficas. Para comprovar essa constatação de que as ficções causam ao homem "mais impressão do que aquilo que é verdadeiro", contrapõe a repercussão obtida pela seriedade dos argumentos que um pregador mobiliza em um sermão mais convencional com a potencialidade expressiva da pregação em que recorre a simples narração de "uma velha história popular ou um milagre da lenda": "eis que o auditório desperta, os que dormitam espertam, todos são olhos e ouvidos" (p. 99). 
Portanto, conforme a hipótese em averiguação, a convivência com as diretrizes criativas da série "Fantasias", estabelecidas por Rigoletto, e a assimilação dos referenciais literários e filosóficos mobilizados no decurso dessas manifestações iniciais, teriam resultado em experimentações fundamentais para a transformação da escrita machadiana e para a sua inscrição na tradição fantástica da sátira menipeia. A apologia da loucura e da fantasia, proclamada por Rigoletto com base na linhagem consolidada por Luciano e por Erasmo, exerceria uma influência decisiva nas opções estético-literárias de Eleazar, como sugere o texto "Elogio da vaidade", inspirado igualmente na obra do humanista holandês e publicado alguns meses depois nessa mesma seção do periódico. A repercussão desse conúbio entre extravagância fantasiosa e irreverência crítica, proveniente da tradição menipeia referenciada por Rigoletto, incidiria também na opção machadiana pela combinação entre alegoria e fantástico, que se manifestaria de maneira expressiva nas crônicas de "Notas semanais" e se consolidaria de maneira irreversível nas obras da "maturidade artística" do escritor, especialmente com Memórias póstumas de Brás Cubas e Papéis avulsos.

\section{A estreia de Eleazar e a continuidade do projeto de Rigoletto}

Antes da publicação dos artigos críticos sobre os romances de Eça de Queirós, o pseudônimo Eleazar fora utilizado por Machado de Assis na assinatura de quatro produções literárias que apareceram nos folhetins de terça-feira: "O bote de rapé" (19 de março), "A sonâmbula" (26 de março), "Um cão de lata ao rabo" (2 de abril) e "O Califa de Platina" (9 de abril). Publicados regularmente nos folhetins de terça-feira, esses textos dariam prosseguimento às manifestações de Rigoletto, tanto no que diz respeito ao estilo fantasioso e humorístico, quanto no propósito de corrigir certos vícios da sociedade de seu tempo.

Os dois primeiros textos apresentam-se como produções de natureza dramática, sendo acompanhados, respectivamente, dos seguintes subtítulos: "Comédia em sete colunas" e "Ópera cômica em sete colunas". Além de firmar uma identidade entre a componente textual e a materialidade do jornal, disposta igualmente em sete colunas, essas duas obras estabelecem um diálogo intertextual com a tradição incorporada pelo editor do periódico ao definir a sua identidade autoral por meio da escolha do pseudônimo Rigoletto - corcunda e bobo da corte da ópera cômica de Giuseppe Verdi. A opção pelo gênero dramático e a inflexão humorística das produções machadianas alinham-se, portanto, ao perfil estilístico esboçado 
pelo iniciador da seção "Fantasias", que, em suas manifestações iniciais, define os paradigmas do conjunto de textos a ser divulgado no espaço do "Folhetim do Cruzeiro" às terças-feiras.

O texto de estreia de Eleazar, "O bote de rapé", assume a forma de uma comédia em versos, com três cenas dispostas em um único ato. A conformação do texto ao reduzido espaço das sete colunas inferiores da página do jornal condicionou, provavelmente, o aspecto ligeiro da situação cômica representada. Dessa natureza textual, resultou talvez a hesitação classificatória dos antologistas ao recolher essa comédia nas edições póstumas da obra machadiana. Reunido em coletâneas de contos e crônicas ${ }^{12}$ ou inserido na diversidade dos textos enfeixados sob a rubrica miscelânea, ${ }^{13}$ a trajetória editorial dessa comédia evidencia uma dificuldade de se aceitar a sua filiação ao gênero dramático, como aconteceria também com outras obras congêneres do autor:

A inclusão de diálogos como Antes da missa e $O$ bote de rapé em volumes de crônicas (lembremos que somente com a edição organizada pelo Instituto Nacional do Livro esses textos foram incorporados à dramaturgia de Machado) e a permanência de Uma ode de Anacreonte no volume Poesias, em sucessivas edições, são exemplos eloquentes da precariedade das classificações de gênero (TORNQUIST, 2002. p. 299).

Desde o seu primeiro texto, observa-se uma predisposição do autor a se ajustar aos paradigmas da série iniciada pelo editor-chefe do jornal. A escolha do gênero textual - uma comédia ligeira, dedicada à representação burlesca de cenas da vida cotidiana, - a inclinação fantástica e a inserção de uma apreciação irônica subliminar a respeito do comportamento feminino - absorvido por uma vaidade egocêntrica e movido e por uma excessiva preocupação com a aparência social, - alinham as cenas de "O bote de rapé" ao programa editorial da série "Fantasias", que tinha em vista a missão de aplainar os desvios humanos e descortinar o véu das hipocrisias sociais por meio do poder de desconstrução das soluções satíricas e humorísticas de seus folhetins.

O segundo texto machadiano publicado nesse contexto de produção, "A sonâmbula", apresenta essa mesma predisposição para o enfoque humorístico, explicitada já no subtítulo da narrativa: ópera cômica em sete colunas. A despeito dessa evocação das convenções elementares de uma ópera, trata-se mais propriamente de uma forma literária que apenas se

\footnotetext{
12 Conferir, por exemplo, a obra Contos sem data, organizada por Raimundo Magalhães Jr (1956, v. 5, p. 231239).

${ }^{13}$ Obra completa, reunida pela editora Nova Aguilar.
} 
apropria da coreografia desse gênero artístico para perfazer os seus fins criativos e efeitos de sentido. Nessas primeiras manifestações fantasiosas remetidas por Machado de Assis ao "Folhetim do Cruzeiro", verifica-se o interessante descortinar de um novo procedimento criativo: a apropriação e a combinação de convenções textuais e gêneros artísticos diversificados com o fim de explorar as suas potencialidades discursivas em favor da construção dos efeitos criativos visados pela obra machadiana. Assim, a segunda fantasia assinada por Eleazar, ao se revestir de ópera cômica, coloca a sua própria forma artística a serviço da representação satírica das práticas charlatanistas denunciadas, definindo-as igualmente como performance teatral, em que prevalece o domínio da ficção e do artifício, da solenidade espetaculosa e da ausência de uma verdadeira fundamentação científica. Portanto, a narrativa machadiana inscreve-se na tradição burlesca da ópera cômica, incorporando seu potencial satírico e humorístico como forma de moralização das práticas sociais.

Na terceira fantasia machadiana, ensaia-se outro recurso de criação decisivo para o novo curso que será seguido pela produção da maturidade: a paródia de estilos literários. Em "Um cão de lata ao rabo", o humor e a extravagância fantasiosa se prestam aos desígnios da assimilação paródica das tendências estilísticas ensejadas no decurso da formação da literatura brasileira. A narrativa constitui um primeiro exemplo de uma solução afortunada no que se refere à singularidade peculiar da dicção irônica e humorística de Machado de Assis. Nessa experimentação, esboça-se um procedimento que servirá de base para a construção de inúmeras outras produções da maturidade: a proposição de simetrias ou silogismos marcados por descompassos ou intervalos irônicos, que resultam no efeito humorístico. ${ }^{14}$ Desse modo, o relato do concurso literário, representado ficticiamente nessa terceira fantasia machadiana, assume uma diç̧ão solene que não condiz com a inegável insignificância de um torneio literário realizado em uma escola de primeiras letras, situada, por sua vez, em um lugarejo provinciano, desprovido de importância histórica. Assim, do interior da simetria estabelecida, emergem a ironia da enunciação e a conotação humorística, inerentes a esse consciente contrassenso da atribuição de gravidade formal ao tratamento de questões disparatadas ou desprovidas de importância real - procedimento que se coaduna plenamente com os

\footnotetext{
14 "A ironia machadiana apoia-se com muita frequência nas simetrias, traduzindo uma situação por outra num eixo de equivalências" (VILLAÇA, 1998. p. 7-10). Conferir também "A Bastilha de Itaguai" (CRESTANI, 2014, p. 184-199).
} 
processos criativos da tradição da sátira menipeia. A dicção irônica e a desproporção cômica encarregam-se de minar a pretensão de novidade dos estilos parodiados, revelando, inversamente, o anacronismo e a alienação do contexto provinciano a que pertencem.

Finalmente, no quarto texto machadiano remetido ao "Folhetim do Cruzeiro", encena-se uma plena integração entre excursão fantástica e representação alegórica de questões polêmicas do Brasil do Segundo Reinado. A ficção machadiana evoca, novamente, convenções culturais e encenações textuais com o propósito de explorar suas potencialidades discursivas em favor da formulação de efeitos de sentido perpassados de conotações satíricas e humorísticas. Exercitando textualmente a coreografia própria de um conto árabe, o texto "O califa de Platina" assimila os elementos peculiares desse segmento cultural com o intuito de estabelecer uma identidade, em tom de denúncia crítica e irônica, entre a inclinação do Oriente Médio para o imaginário fabuloso das histórias maravilhosas, encantamentos e truques mágicos, e a ardilosa artimanha da República Argentina para com o Brasil na deliberação de fechar os seus portos sob o pretexto de se proteger da febre amarela, dissimulando, assim, o escuso interesse de macular a imagem do Brasil diante da Europa e se beneficiar na acirrada disputa pelo afluxo de imigrantes europeus num período de urgente necessidade de substituição do regime de trabalho servil.

$\mathrm{Na}$ análise dessa narrativa, observa-se que a apropriação de técnicas provenientes da tradição luciânica, em vez de corroborar a afirmação da imagem universalista do escritor, apregoada pela fortuna crítica, evidencia o seu direcionamento à intervenção artística em assuntos polêmicos de seu tempo, desvelando sua interação dinâmica com o conjunto de discursos, códigos e signos que formam a cultura do período.

Em síntese, constata-se a deliberada percepção de Machado de Assis de que o estilo insólito seria o mais adequado para formalizar esteticamente os contrassensos que emergiam dos mais diversos setores da sociedade brasileira. O disparate e a fantasia extravagante consistiriam, portanto, na margem possível para o escritor apreender literariamente o universo social no qual estava inserido.

\section{Considerações finais}

No decurso deste artigo, observou-se que a incursão do escritor na dinâmica editorial do periódico e a continuidade do programa criativo engendrado por Rigoletto resultaram em 
consequências afortunadas para o processo de reinvenção de Machado de Assis. Desde a sua primeira manifestação à frente do folhetim de terça-feira, observa-se uma predisposição a se ajustar aos paradigmas da série iniciada pelo editor-chefe do jornal, os quais contribuiriam decisivamente para a irrupção de uma dicção emblemática do que se convencionou chamar de estilo machadiano.

Assim, na análise da produção remetida por Machado de Assis ao "Folhetim do Cruzeiro", verificou-se a propensão do escritor para a apropriação e a combinação de convenções textuais e gêneros artísticos diversificados com o fim de explorar as suas potencialidades discursivas em favor da construção de efeitos criativos, com uma frequente predisposição para a inclinação humorística e para a irreverência crítica. Em outras manifestações da série, observou-se também que o humor e a extravagância fantasiosa se prestam aos desígnios da assimilação paródica das tendências estilísticas ensejadas no decurso da formação da literatura brasileira. Nas representações de cunho alegórico, constatou-se a opção artística do autor por um estilo insólito e extravagante como alternativa mais apropriada à formalização estética dos contrassensos que emergiam dos mais diversos setores da sociedade brasileira.

Em suma, pode-se considerar que o conjunto de inovações consolidadas nas fantasias machadianas divulgadas no âmbito do "Folhetim do Cruzeiro" inclui a subversão e relativização dos paradigmas e valores do senso comum em prol da instituição de uma visão de mundo paradoxal e desconcertante; a suspensão do equilíbrio dos gêneros puros da tradição literária em favor da liberdade de combinação das potencialidades discursivas das mais diversas modalidades textuais; a preterição do estilo sério e da perspectiva crítica e edificante em proveito da manifestação deliberada do deboche irônico, do tom desabusado e da desfaçatez e impostura da instância enunciativa; o escamoteamento dos protocolos da mimese e da verossimilhança narrativa em benefício da extravagância fantasiosa, do humor irreverente e da apropriação paródica de modelos literários anacrônicos.

Portanto, a despeito da complexidade intrínseca à excepcional metamorfose machadiana, este estudo procurou demonstrar que esse processo de transformação não se trata de um fenômeno absolutamente inextrincável, mas de uma busca consciente e deliberada do escritor, que investiu obstinadamente na experimentação de uma nova elocução artística ao longo de sua colaboração semanal junto ao periódico O Cruzeiro. Em 
cada manifestação desse repertório textual, visualizam-se expressivos acréscimos para o delineamento dos traços representativos do novo autor em gestação, que se consagraria como um referencial inalienável da literatura brasileira.

\section{REFERÊNCIAS BIBLIOGRÁFICAS}

ASSIS, Joaquim Maria Machado de. Obra completa em quatro volumes. Rio de Janeiro: Aguilar, 2008, 4 vols.

. Crítica teatral. Rio de Janeiro: Jackson, 1951. v. 30.

BAKHTIN, Mikail. Problemas da Poética de Dostoiévski. 3. ed. Traduzido por Paulo Bezerra. Rio de Janeiro: Forense Universitária, 2002.

CRESTANI, Jaison Luís. A Bastilha de Itaguaí. In: . Machado de Assis e o processo de criação literária. São Paulo: Edusp/Nankin Editorial, 2014.

ERASMO. Elogio da loucura. Trad. Ana Paula Pessoa. São Paulo: Sapienza, 2005.

FACIOLI, Valentim. Um defunto estrambótico: análise e interpretação das Memórias póstumas de Brás Cubas. São Paulo: Nankin Editorial, 2002.

LUCIANO DE SAMOSATA. Diálogos dos mortos. Tradução e notas de Maria Celeste Consolin Dezotti. São Paulo: Hucitec, 1996.

MERQUIOR, José Guilherme. Gênero e estilo nas Memórias póstumas de Brás Cubas. In: ASSIS, Machado de. Obra completa em quatro volumes. v. 1. São Paulo: Aguilar, 2008, p. 139-146.

O CRUZEIRO. Rio de Janeiro. 1878.

REVISTA ILLUSTRADA. Rio de Janeiro. 1877-1883.

SÁ REGO, Enylton de. O calundu e a panaceia: Machado de Assis, a sátira menipeia e a tradição luciânica. Rio de Janeiro: Forense Universitária, 1989.

SOUZA, Silvia Cristina Martins de. Um Offenbach tropical: Francisco Correa Vasques e o teatro musicado no Rio de Janeiro da segunda metade do século XIX. História e Perspectivas, Uberlândia, n. 34 , jan.jun.2006, p. 225-259.

TEIXEIRA, Ivan. Apresentação de Machado de Assis. São Paulo: Martins Fontes, 1987.

. Pássaro sem asas ou morte de todos os deuses. Uma leitura de Papéis avulsos. In: ASSIS, Joaquim Maria Machado de. Papéis avulsos. Edição e introdução de Ivan Teixeira. São Paulo: Martins Fontes, 2005. 2010.

. O altar e o trono: dinâmica do poder em O alienista. São Paulo: Ateliê Editorial; Ed. UNICAMP,

TORNQUIST, Helena. As novidades velhas: o teatro de Machado de Assis e a comédia francesa. São Leopoldo-RS: Unisinos, 2002.

VILLAÇA, Alcides. Janjão e Maquiavel: a Teoria do Medalhão. In: GUIDIN, Márcia Ligia; GRANJA, Lúcia; RIClERI, Francine Weiss (orgs.) Machado de Assis: ensaios da crítica contemporânea. São Paulo: Ed.UNESP, 2008, p. 31-54. 